\title{
ANALYSIS OF DAM HOLDER PLANNING (GULLY PLUG) FOR SEDIMENT CONTROL IN CATCHMENT AREABRANTAS RIVER
}

\author{
Nanang Dwi Cahyono \\ nanang.dec@gmail.com \\ Faculty of Engineering \\ Civil Engineering Study Program \\ Narotama University Surabaya, Jl. Arif Rahman Hakim 51 Surabaya
}

\begin{abstract}
Catchment Area Konto River is part of the Upper Brantas watershed, which is located in Pujon and Ngantang Regencies with an area of $236 \mathrm{~km}^{2}$. Located on.Kontoriver and many weathered areas on the mountain slopes around the reservoir. The Selorejo Dam was built in 1972 as a multipurpose dam for the supply of irrigation water, power plants, electricity and flood control. The reservoir which is planned to have a technical age reaches 100 years, but the technical life is reduced due to siltation of the reservoir. The gross storage capacity of the Selorejo Reservoir has decreased to 38.25 million $\mathrm{m} 3$, or $61.4 \%$ of the initial gross storage capacity of 62.30 million $\mathrm{m} 3$. The process of reducing capacity, moderate storage reservoirs compared with, other reservoirs in the Brantas watershed based on the results of monitoring sedimentation Selorejo Reservoir sedimentation rate of 0.72 million $\mathrm{m} 3$ / yr. According to Karen, action is needed to deal with this matter so that the reservoir can function optimally

Measures for sediment management that have been carried out in catchment management through conservation activities, river channel management as a reduction of sediment inflow to reservoirs, through the construction of technical civil structures, namely gully plug. There are also activities that have been carried out by diverting sediment so that it does not pass through the reservoir (by pass). Reservoir sedimentation management by operations and flushing
\end{abstract}

Keywords: Sedimentation reservoir, discharge draft, building catcher sedi ment

\section{INTRODUCTION}

Reservoir is one of the multipurpose dams for the supply ofiriigation water, electricity generation and flood control. Reservoir sedimentation is a problem that is faced in almost all in the management of dams / reservoirs, because the existence of reservoir construction has caused changes in the river drainage system that allows sedimentation / sedimentation. Sedimentation has caused a reduction or loss of reservoir reservoir volume which certainly has an impact on the declining value of the reservoir utilization.

The morphology of the Brantas River Basin starts from rivers in the mountains, rivers in transition regions, to rivers in the east or tidal areas. River morphology in the mountainous area has a high river bank with a slope of a large (steep) river bed, for the transition / middle region has a rather wide base slope with a rather low river bank, while in the plain area have a sloping base and a low river bank.

\section{Existing Sediment Balance in the Brantas River Basin}

Sediment balance analysis is needed as basic data to conduct a comprehensive study of sediment management in the Brantas River Basin. The results of the study on 


\section{Volume 03 Number 02 Maret 2020}

the balance of sedimentation in reservoirs are used to determine the plan for the management of reservoir sediments through sediment extraction activities in dams by dredging or flowing sediment downstream through flushing, which is then used as a basis for analyzing the stability of the Brantas river bed in the middle and downstream

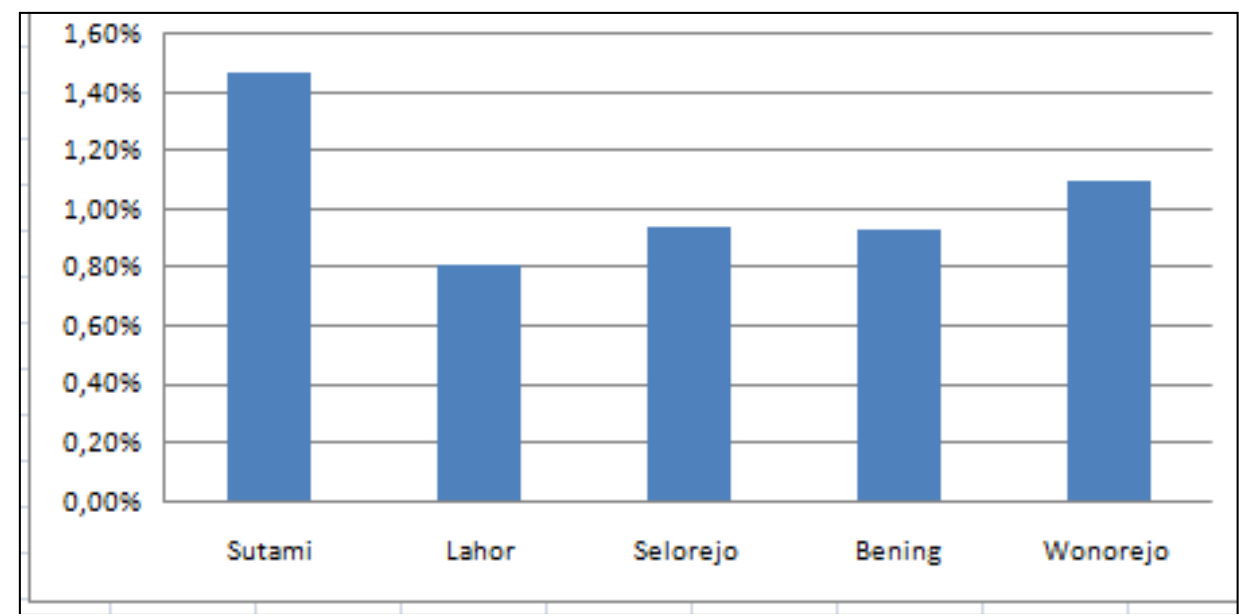

Figure 1. Percentage Decreased Reservoir Capacity In the Brantas River Basin

Over time, the reservoir will fill with sediment. As sediment deposits increase, reservoirs become less effective so they can no longer operate as planned. With these conditions in mind, reservoir sediment management is carried out in order to provide sustainable benefits.

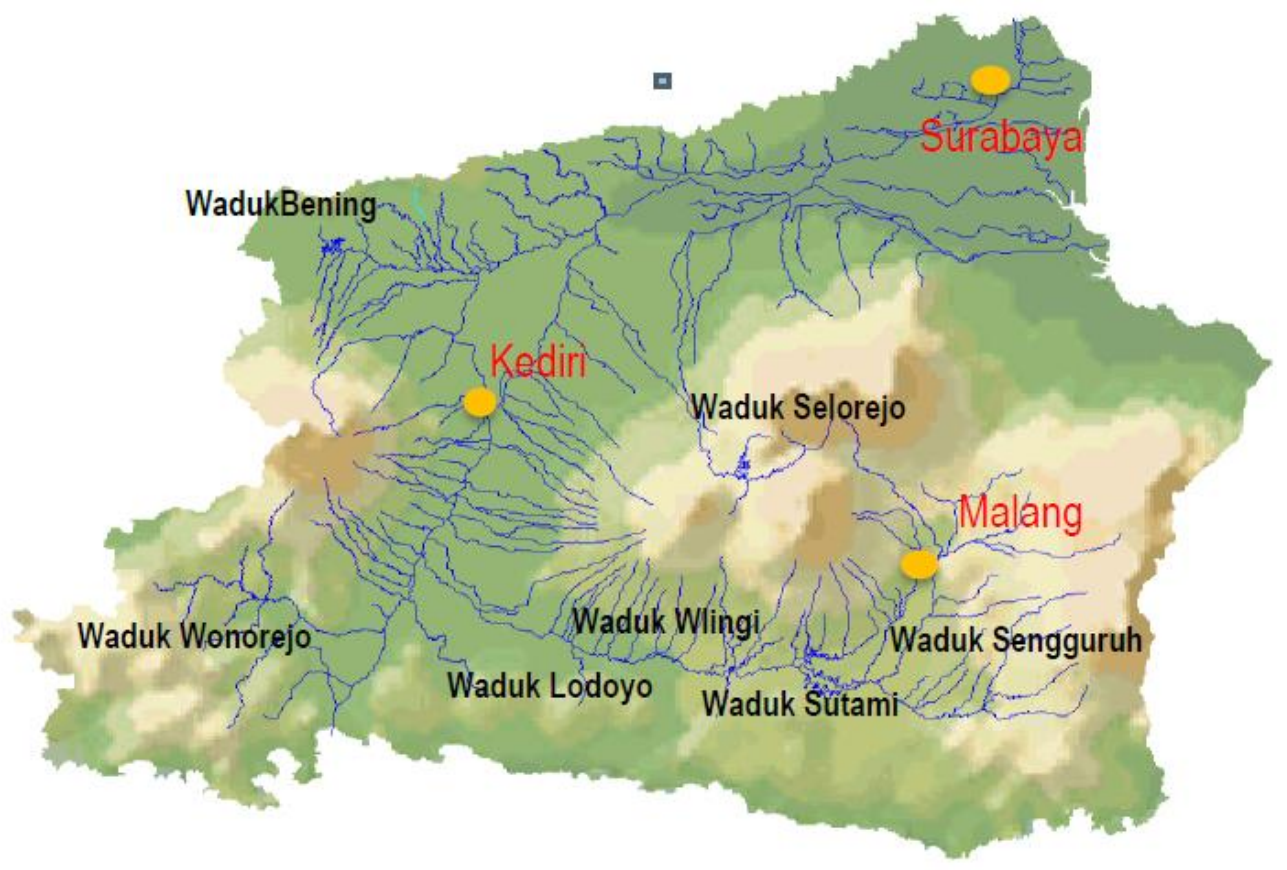

Figure 2. Reservoirs in the Brantas River Basin.

\section{Upper Brantas Watershed}


The Kali Brantas Hulu sub-watershed is located in the highlands along Anjasmoro Mountain, Arjuno Mountain, Mount Kawi, Mount Bromo, Mount Semeru, Mount Butak and Mount Kelud. This area has a slope between $6^{\circ}-42^{\circ}$ with elevation between 500 - $1000 \mathrm{~m}$. The geology of the Upper Brantas Upper watershed generally consists of Holocene and Pleistocene volcanic rocks and tertiary sedimentary rocks. Soil types in the Upper Brantas watershed can be classified into 8 (eight) groups, namely Andosols, Regosols, Mediterans, Brown Forests, Litosols and Latosols. Whereas the types of land use in the Brantas Hulu sub-watershed are forests, dry fields, irrigated fields, plantations and settlements with the highest percentage being irrigated fields and plantations.

With the increasing land requirements in the Upper Brantas Upper watershed, many lands whose capabilities are not suitable for agricultural purposes are converted to agricultural areas without properly conserving land and water. This condition significantly increases the amount of critical land.

\section{Selorejo Reservoir}

The Selorejo Dam, which has a reservoir area of $236 \mathrm{~km} 2$, is located on the Konto River and there are many weathered areas on the mountain slopes around the reservoir. The Selorejo Dam was built in 1972 as a multipurpose dam for the supply of irrigation water, electricity generation and flood control. The gross storage capacity of the Selorejo Reservoir has decreased to 38.25 million $\mathrm{m} 3$, or $61.4 \%$ of the initial gross storage capacity of 62.30 million $\mathrm{m} 3$. The process of decreasing the storage capacity compared to other reservoirs in the Brantas River Basin

\section{Konto Watershed}

\section{RESEARCH METHOD}

The Konto watershed is located in the highlands along Kelud Mountain, Mount Wilis, Gunung Kawi and Gunung Gentong-Gowok. This area has a slope between $8^{\circ}$ - $43^{\circ}$ with elevation between 500 - 1,200 m. The Konto sub-watershed consists of Pleistocene and Holocene volcanic rocks. Soil types in the Konto subwatershed can be classified into 4 (four) groups, namely Regosol, Andosol, Latosols and the Mediterranean. While the types of land use found in the Konto sub-watershed are forests, dry fields, irrigated fields, plantations and settlements with the highest percentage being irrigated fields and forests .

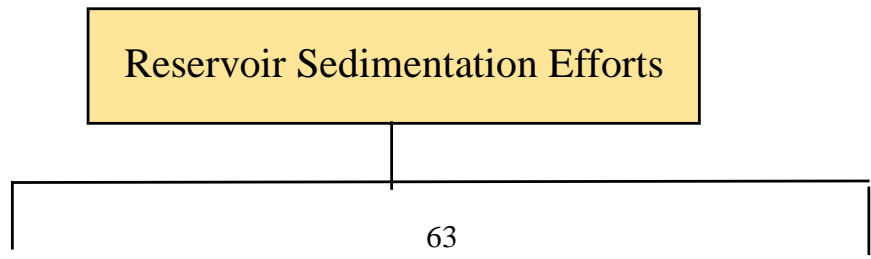


Handling Cathment Area

- Land Conservation

- Cliff and Slope Protection

- Making sediment diversion channels

- Making sedimentary Bags ( Gully Plug )
Storage Handling

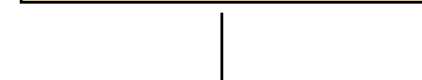

- Dredging

- The Reservoir is Dead

- Flushing

- Downstream Flue Dredging

Figure 3. Reservoir Management Sediment

\section{Sediment Control Business}

\section{RESULT AND DISCUSSION}

A. Carry out land conservation to conserve land and water (land and water conservation) by building a gully plug.

B. On empty lands that are prone to erosion must be reforested immediately (reforestation) in order to reduce the sediment rate also functions as soil and water conservation.

C. 3 Areas that have a sharp slope, land management must be parallel to the contour line (terracing) so that it can hold the sediment rate 


IJTI (International Journal Of Transportation And Infrastructure)
Available Online @ http://ju mal.na rota ma.ac.id/index.php/ijti
ISSN : 2597-4769 (ONUNE) ISSN : 2597-4734 (CETAK)

Volume 03 Number 02 Maret 2020

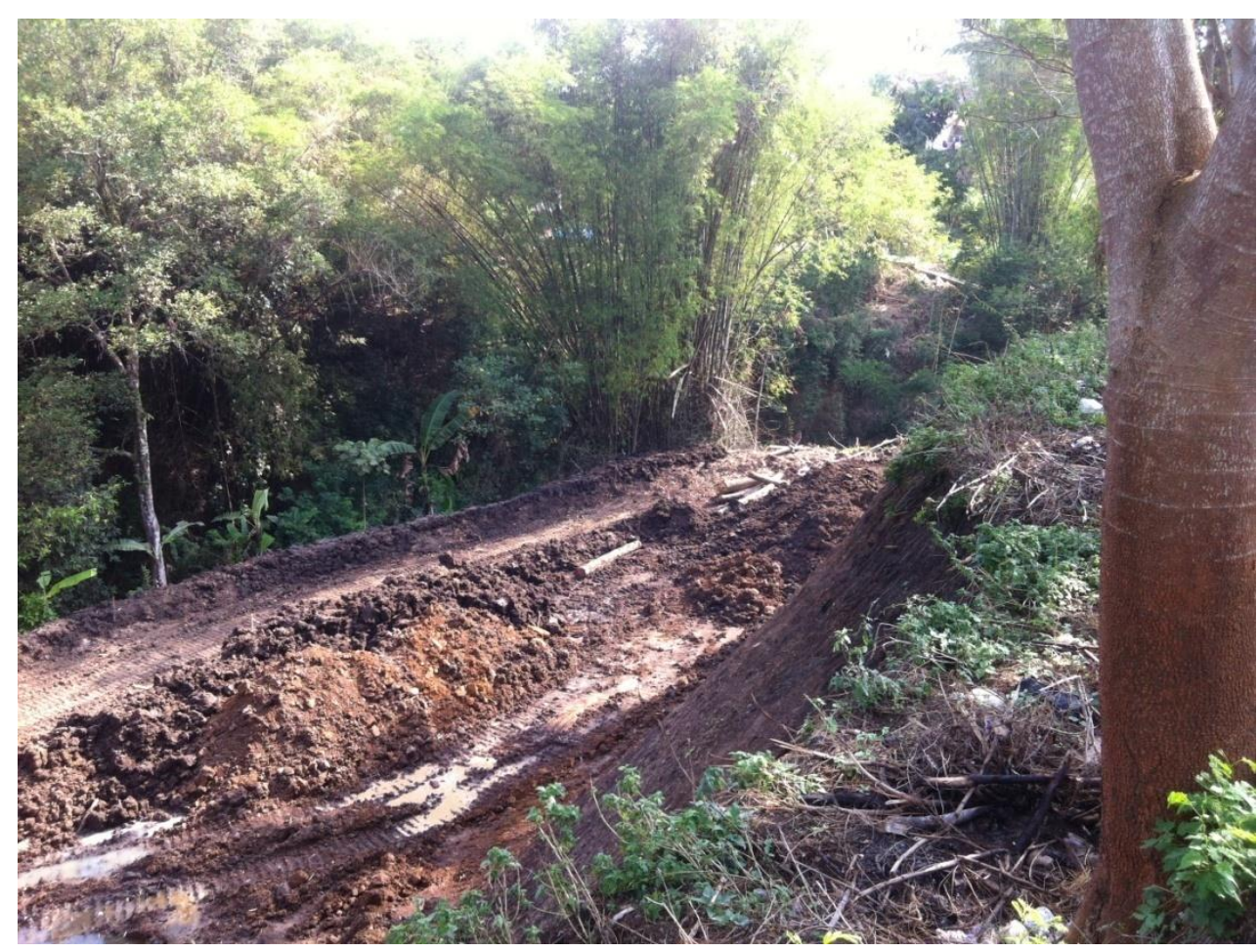

Figure 4. Land Erosion Conditions

A gully plug is a small dam that escapes water by constructing gabions, river stones and wood / bamboo crucifixes made in creeks / ravines. The benefits of gully plugs are to control sedimentation and surface water flow from the catchment area upstream and increase groundwater surface downstream. The building was made on land plots that could potentially cause erosion

The process of water flow initially penetrates the stone-filled gabion and then a sedimentary buildup occurs in the upper reaches of the building. Calculation of storage volume (storage) can describe the relationship between land surface elevation with the area of inundation and storage volume (storage).

$$
V=1 / 2 \frac{B \cdot \mathrm{HM}^{2}}{\mathrm{LO}-\mathrm{LS}}
$$

Where:

$$
\begin{aligned}
& \mathrm{V}=\text { sediment volume }\left(\mathrm{m}^{3}\right) \\
& \mathrm{B}=\text { river width }(\mathrm{m}) \\
& \mathrm{hm}=\text { effective height }(\mathrm{m}) \\
& \mathrm{lo}=\text { river bed slope exiting }(\mathrm{m}) \\
& \mathrm{l} \mathrm{s}=\text { stable river bed slope }(\mathrm{m})
\end{aligned}
$$

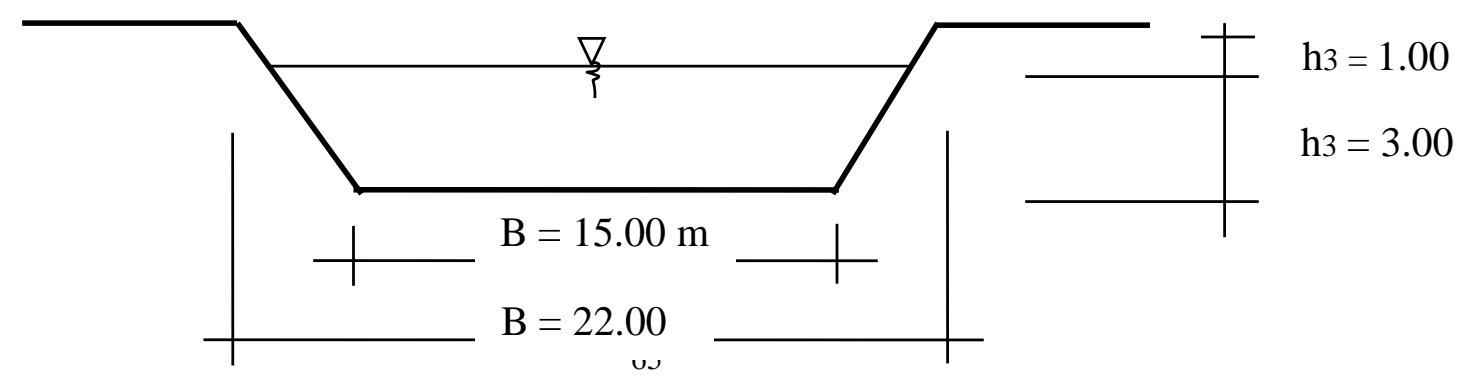




\section{Volume 03 Number 02 Maret 2020}

From the calculation of the discharge obtained water level plan above the boiler (h3) of $3.00 \mathrm{~m}$. While the width of the upper boiler is $22.00 \mathrm{~m}$, the width of the bottom boiler is $15.00 \mathrm{~m}$. The guard height (h3) is $1,00 \mathrm{~m}$ and the volume of sediment storage upstream of the Gully Plug is $277.50 \mathrm{~m}^{3}$ with a full sedimentation time of 288 hours (2 years during rainy season)
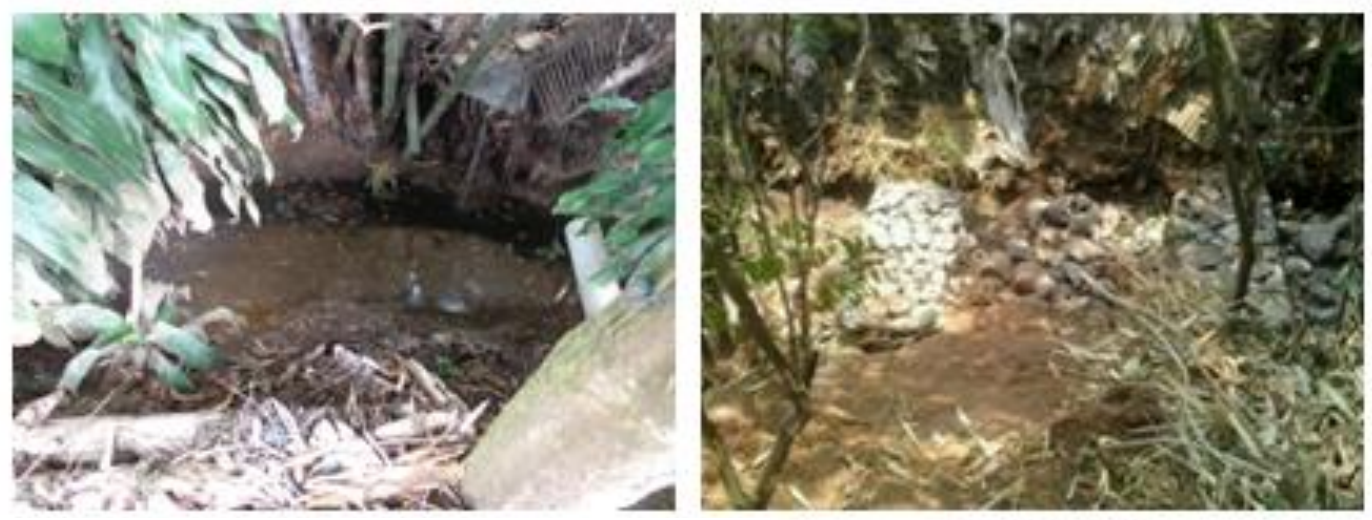

Condition 0\% ( before implemented )

Condition $10 \%$ ( basic foundation )

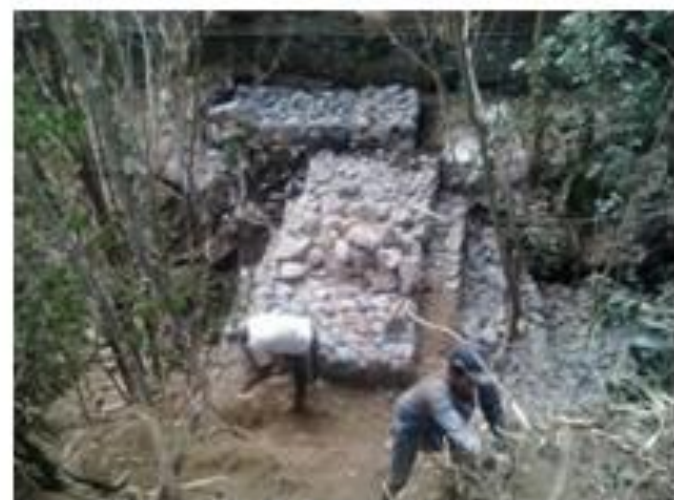

Condition 50\% ( implementation process )

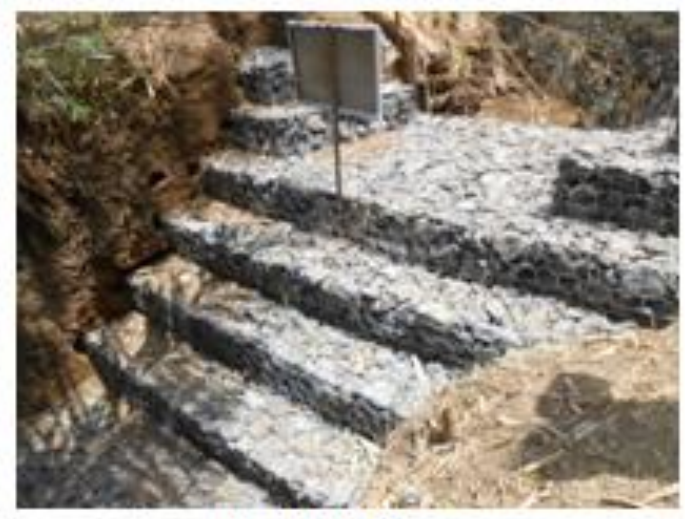

Condition $100 \%$ ( implementation is complete )

Figure 5. The Process of Making a Gully Plug

\section{CONCLUSION}

Based on the data and the results of Gully Plug planning calculations the following conclusions are obtained:

1. Design flood discharge using the Nakayasu Method with a 50-year return period was obtained $8.275 \mathrm{~m} 3$

2. The volume of sediment storage upstream of the Gully Plug is $277.50 \mathrm{~m}^{3}$

3. From the analysis of sediment and hydraulics analysis, the gully plug dimension is $4.00 \mathrm{~m}$ high gully plug, $3.00 \mathrm{~m}$ sub gully plug height, $2.00 \mathrm{~m}$ main gully plug foundation depth, $1,00 \mathrm{~m}$ gully plug foundation depth, downstream slope main gully plug and sub gully plug 1: 0,20 . The upstream slope of the main gully plug and sub gully plug 1 : 1.00 , apron length $5 \mathrm{~m}$ and thickness apron $1.00 \mathrm{~m}$.

Based on the existing dimensions of the gully plug, the stability of the gully plug against shear and rolling forces is SF> 1.5 in conditions without earthquake and SF>, 2 in earthquake conditions. While the stability of the carrying capacity of the soil is omax< <ijin and omin> 0 , as well as the stability of the calculated $\mathrm{C} 1$ piping $>\mathrm{C} 1$. Then it can be 
Volume 03 Number 02 Maret 2020

concluded that the stability of the gully plug has fulfilled the requirements and the construction is safe.

\section{REFERENCES}

03-2851, S. (1991). Tata Cara Perencanaan Teknik Bendung Penahan Sedimen.

Anonymous. (1986). Perencanaan Bangunan Pengendalian Sedimen. Volcanic Sabo Tecnical Centre, Yogyakarta.

Anonymous. (2008). Profil Balai Besar Wilayah Sungai Brantas. Surabaya.

Anonymous. (1985). Sabo Design. Volcanic Sabo Tecnical Centre, Yogyakarta.

Chow, V. (1992). Hidrolika Saluran Terbuka. Cetakan ketiga, Erlangga, Jakarta.

Kamiana, I. M. (2001). Teknik Perhitungan Debit Rencana Bangunan Alr. Graha IImu, Yogyakarta.

P.6/PDASHL/SET/KUM.1/8/2017. (2017). Petunjuk Teknis Bangunan Konservasi Tanah dan Air. Peraturan Direktur Jenderal Pengendalian Daerah Aliran Sungai dan Hutan Lindung.

Perum Jasa Tirta 1. (2019). Pengukuran Echosounding Waduk Selorejo. Malang: Buku II, Data Sedimen.

Prastumi. (2008). Bangunan Air. Cetakan pertama, Srikandi, Surabaya.

Soedibyo. (1993). Teknik Bendungan. PT. Pradnya Paramita, Jakarta.

Sosrodarsono. (1983). Mekanika Tanah dan Teknik Pondasi. Cetakan kedua, PT Pradnya Paramita, Jakarta.

Sosrodarsono, S. (2003). Hidrologi Untuk Pengairan.

Subarkah, I. (1980). Hidrologi Untuk Perencanaan Bangunan Air. Idea Dharma, Bandung.

Sunggono, K. (1984). Mekanika Tanah. Nova, Bandung 